\title{
Online data repositories and resources
}

D ata literacy in politics and international relations research is an important skill for university students and academic librarians. More broadly, such literacy is crucial for developing nations and agencies of the United Nations (UN). The first UN World Data Forum will be hosted by Statistics South Africa (Stats SA) January 15-18, 2017, ${ }^{1}$ with support from the Statistics Division of the UN Department of Economic and Social Affairs (DESA), overseen by the United Nations Statistical Commission and the High-level Group for Partnership, Coordination and Capacity-Building for Statistics for the 2030 Agenda for Sustainable Development. ${ }^{2}$ This will be an important event for UN member states and agencies to focus on capacity development for better data and developing human capacity for data and statistics.

Data quality, availability, and promotion should center on "empowering citizens and communities as free agents. This can only be achieved by considering data literacy as a significant means and metric for social inclusion," which can also be called data inclusion. ${ }^{3}$ This has implications for students researching the UN, its member states, agencies, and initiatives. Formats are improving to quickly access datafriendly formats. For example, users can download population and migration tables in Excel format from the UN 2016 Statistical Yearbook. ${ }^{4}$ Additionally, the UN Statistics Division produced The World's Women 2015: Trends and Statistics. Users can download a chapter, but they can also download the data online at http://unstats. un.org/unsd/gender/worldswomen.html. Vari- ous UN data repositories, initiatives, and datarelated websites are outlined in this column.

\section{Data repositories}

- Humanitarian Data Exchange. This open data-sharing platform is maintained by the UN's Office for the Coordination of Humanitarian Affairs (OCHA). The goal of HDX is to make humanitarian data easy to find and use for analysis. Launched in July 2014, HDX has been accessed by users in more than 200 countries and territories. This site can be searched by data, location, organization, or such specific crises as El Nino or Ebola. OCHA Afghanistan and the World Food Programme have more than 20 data sets each. This is useful for diplomacy and global or public health students. Access: https:// data.humdata.org/.

- UNdata. This is a statistical portal produced by the UN Statistical Division that allows simultaneous searching of 24 databases from UN Statistics and Population Divisions, UN specialized agencies (International Labour Organization, Food and Agriculture Organization [FAO],

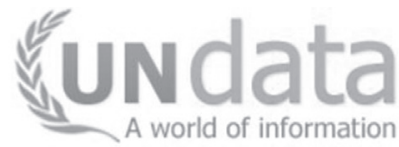
W o $\quad \mathrm{r} l \mathrm{~d}$ Health Or- permission of the United Nations

Lisa DeLuca is social sciences librarian and liaison to the School of Diplomacy and International Relations at Seton Hall University, email: lisa.deluca@shu.edu

(C) 2017 Lisa DeLuca 
ganization), and member states (statistics collected by the national statistical agencies of member states). It is a metasearch of statistics collected from all those various bodies. Access: unstats.un.org.

- UNStats. This is the website of the UN Statistical Division, within the Department of Economic and Social Affairs (DESA) of the UN Secretariat. It contains the statistics collected by the statistical division, publications produced by

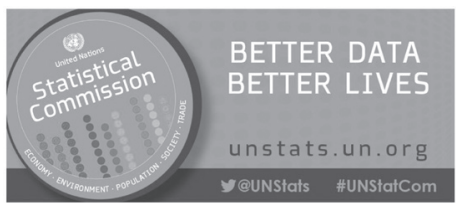

(c) 2017 United Nations. Reprinted with the permission of the United Nations. the statistical division, and i n f o r mation about the division's work. It will not have the statistics collected by the UN specialized agencies or the Member Countries. Access: http://unstats.un.org.

\section{Initiatives}

- Global Health Observatory. This is the entry point to the World Health Organization's database of 1,000 indicators in more than 194 countries. Data is organized to track progress of health-related sustainable development goals. Access: http://www.who.int/gho/en/.

- Global Sustainable Development Goals (SDGs) Indicators Global Database. This database is managed by the UN Statistics Division and allows views by indicator, by country, or by area that can be downloaded to Excel or CSV format. The UN Environment Programme Knowledge Repository contains maps for SDG synergies, region, or theme and is described below. Access: http://unstats.un.org/sdgs /indicators/database/.

- UN World Data Forum. As refer-

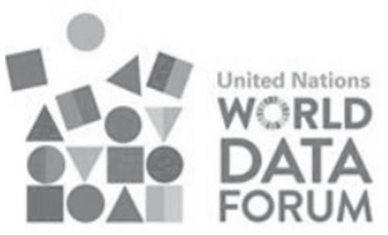

(c) 2017 United Nations. Reprinted with the permission of the United Nations. enced above, this website also contains blog posts that relate to data literacy as an agent for change and social inclu- sion. Access: http://undataforum.org/.

\section{Country data}

- African Centre for Statistics. The UN Economic Commission for Africa has established this Centre for member states seeking original data to inform policy decisions. The African Centre for Statistics is intended to serve as a regional data hub for economic, social, demographic, and environmental conditions in African countries. Access: http://www.uneca.org/acs.

- CountryData. From the UN Statistics Division, national and international data is available here to track development progress at the country level. Access: http://data.un.org /countryData/.

- European Countries. The Statistical Database of the Economic Commission for Europe (ECE) country profiles for ECE member countries, including population, migration, economy, transport, and forestry. Access: http://w3.unece. org/PXWeb/en.

- Geospatial Information. This portal is maintained by the UN Initiative on Global Geospatial Information Management. The country section showcases best practices and case studies to illustrate the successful use of geospatial information. The portal also provides key references and documents on National Spatial Data Infrastructures. Access: http://ggim. un.org/country\%20reports.html.

- Latin America. The ECLAC Digital Repository is maintained by the Economic Commission for Latin America and the Caribbean. A section for Data \& Statistics contains La Comisión Económica para América Latina's CEPALSTAT, the gateway to all the statistical information of Latin America and the Caribbean countries collected, systematized, and published by ECLAC. Access: http://www.cepal.org/en /datos-y-estadisticas.

- OECD.stat. Managed by the Organisation for Economic Co-operation and Development (OECD), this site allows users to browse by topic or country. It includes data and metadata for OECD countries and selected nonmember economies. Access: https://data.oecd.org/ or http://stats.oecd.org/Index.aspx.

- UNCTADStat. This site was created by the UN Conference on Trade \& Development. It houses data and country profiles including more 
than 150 indicators and statistical time series. Access: http://unctadstat.unctad.org/EN/.

- World Bank Open Data. World DataBank is an analysis and visualization tool that contains collections of time-series data that users can view by indicators, countries, or regions. Access: http:// databank.worldbank.org/data/home.aspx.

\section{Demographics and migration}

- Demographic and Social Statistics. This is the main page of the UN Statistical Division, where users can search by demographic and social topics (population size and density, family formation, violence against women, etc.). This site links to databases and publications covering demographics, housing, and women and gender issues. Access: http://unstats.un.org /unsd/demographic/default.htm.

- Gender Equality. View specifics about the minimum set of gender indicators, including qualitative and quantitative indicators relating to health, education, public life, and human rights of women and children. Access: http:// genderstats.un.org/.

- Human Development Reports. Made available from the UN Development Programme, these include Human Development Data from 1980 to 2015, the Human Development Index, and Google's Public Data Explorer. Access: http://hdr.undp.org/en/data.

- International Migration. This site from the Population Division of DESA contains international migration flow datasets and migration profiles from 2011 to 2015. Access: http:// www.un.org/en/development/desa/population /migration/data/index.shtml.

- UN Population Information Network. This site features the World Population Prospects Database, Demographic Yearbooks, and Global and Regional Population Distribution. The site aggregates data from multiple UN agencies, including the Statistics Division, Population, UNHCR, UNAIDS, and others.) Access: http:// www.un.org/popin/data.html.

\section{Thematic issues}

\section{Environment}

- Energy. The Energy Statistics Database contains basic statistics for more than 220 countries/territories. For a fee, the database provides time series for the period 1950 to 2013 and is updated annually. The most recent four years in the database are disseminated through the Energy Statistics Yearbook and the Energy Balances and Electricity Profiles. Data from 1990 to 2013 are available online through the UNdata portal. Access: http://unstats.un.org /unsd/energy/edbase.htm.

- Environmental Data Explorer. This is the authoritative source for datasets used by the United Nations Environment Programme (UNEP) and the Global Environment Outlook partners. The database contains more than 500 different variables as national, regional, and global statistics or as geospatial datasets (maps), covering such themes as fresh water, population, forests, emissions, climate, disasters, health, and GDP. This site allows users to create maps, graphs, or data tables, or to download the data in different formats. Access: http://geodata.grid. unep.ch/.

- Global Environment. The UNEP Knowledge Repository is a resource for global environmental issues, including climate change, disasters and conflicts, ecosystem management, environmental governance, chemicals and waste, and resource efficiency. There is not a data section, but a search for "dataset" within this site links to more than 7,000 sources for data, including Gender-Environment Datasets with Broadest Country Coverage, which is available at http://web.unep.org/ggeo/resources /data-sources. This repository contains maps for Sustainable Development Goal synergies, region, or theme. Access: http://www.unep.org /publications/.

- Global Gender and Environment. The Global Gender and Environment Outlook is a collaborative project between UNEP and strategic partners to bring gender issues to the heart of environmental assessment and decision making. To date, 17 indicators pull from available UN data, separated by gender, on environment and sustainable development issues. Access: http://web.unep.org/ggeo/resources /data-sources.

\section{Food and agriculture}

- AQUASTAT. This is Food and Agriculture 
Organization's (FAO) global water information system, developed by the Land and Water Division. The most quoted source on global water statistics, this portal includes maps, summary and spatial tables, and datasets. Access: http://www.fao.org/nr/water/aquastat /main/index.stm.

- Countrystat. This is an open source platform for food and agriculture statistics, including national and subnational levels. The goal of this platform is to act as a portal for statistics from member states. A useful e-learning course is available for CountrySTAT to upgrade statistical and technical skills of member states to improve data collection, quality and storage of food, and agricultural data. Access: http:// www.countrystat.org/.

- FAOSTAT. This is the repository for production, trade, and emissions data related to agriculture and land use for the Statistics Division of the FAO. Data includes emissions for agriculture and land use, food security, population, trade, and production. Access: http://faostat3.fao. org/home/E.

\section{Health and development}

- UNHCR Population Statistics Database.

This database maintained by the United Nations High Commissioner for Refugees (UNHCR) shows data about populations of concern from 1951 to 2014 and allows users to view general composition by location of residence or origin, status (refugees, asylum seekers, internally displaced persons, etc.) and evolution. Access: http://popstats.unhcr.org/en/overview\# ga=1.48899941.2125365178.1478814004.

- UN Human Development Index. Allows experts to keep up (through 2015, at present) with data relevant to health, education, and standard of living, and to compare a country of expertise with most others in the world. Access: http://hdr.undp.org/en/data.

- UNICEF. The United Nations International Children's Emergency Fund (UNICEF) houses data including child mortality, health and nutrition, maternal health, water and sanitation, education, child migration and displacement, child protection, and HIV/AIDS. Users can view statistics by topic or country. Access: https:// data.unicef.org/.

- World Health. WHOSIS is the World Health Organization's Statistical Information System that has been incorporated into the Global Health Observatory to provide researchers with more data, tools, analysis, and reports. Access: http://www.who.int/whosis/en/.

\section{Trade and Commerce}

- COMTRADE. The United Nations Commodity Trade Statistics Database (UN COMTRADE) contains detailed goods imports and exports statistics reported by statistical authorities of nearly 200 countries or areas. It concerns annual trade data from 1962 to the most recent year. UN COMTRADE is considered the most comprehensive trade database available, with more than 3 billion records. Access: http://comtrade.un.org/.

\section{UN Comtrade Database}


chaired by the UN Secretary-General. Access: http://www.unsceb.org/directory.

- Military expenditures. The UN Office for Disarmament Affairs produces the United Nations Report on Military Expenditures. Choosing Databases and Research tools, users can view GA Resolutions and Decisions, Disarmament Treaties, the Military Expenditures Database, and the Global Reported Arms Trade. Access: https:// www.un.org/disarmament/convarms/milex/.

- Treaties. The UN Treaty Collection describes the Treaty Section of the UN Office of Legal Affairs, including Depositary of Treaties, Registration and Publication of Treaties, resources that include the Treaty Handbook in six languages and training. Access: https:// treaties.un.org/.

- UN Enterprise Search. An exciting advancement is the UN Enterprise Search tool that can search for data in six languages. Searching with the word dataset will also be helpful. Users can search for websites, documents, videos, images, social media, and data. As more divisions of the UN are added, finding data will continue to be easier. The enterprise search currently includes the Department of Economic and Social Affairs and the Office of Administration of Justice. Access: https://search.un.org.

\section{Notes}

1. United Nations World Data Forum, http://undataforum.org/WorldDataForum /programme/ (accessed November 10, 2016).

2. Statistics South Africa, www.statssa.gov. $\mathrm{za} /$ (accessed: November 21, 2016).

3. Rahul Bhargava and Erica Deahl and Emmanuel Letouzé and Amanda Noonan and David Sangokoya and Natalie Shoup, "Beyond Data Literacy: Reinventing Community Engagement and Empowerment in the Age of Data," DATA-POP ALLIANCE, http://datapopalliance.org/item/beyond-data -literacy-reinventing-community-engagement -and-empowerment-in-the-age-of-data/ (accessed November 21, 2016).

4. The Statistical Yearbook, http://unstats. un.org/unsd/publications/statistical-yearbook (accessed November 21, 2016). n

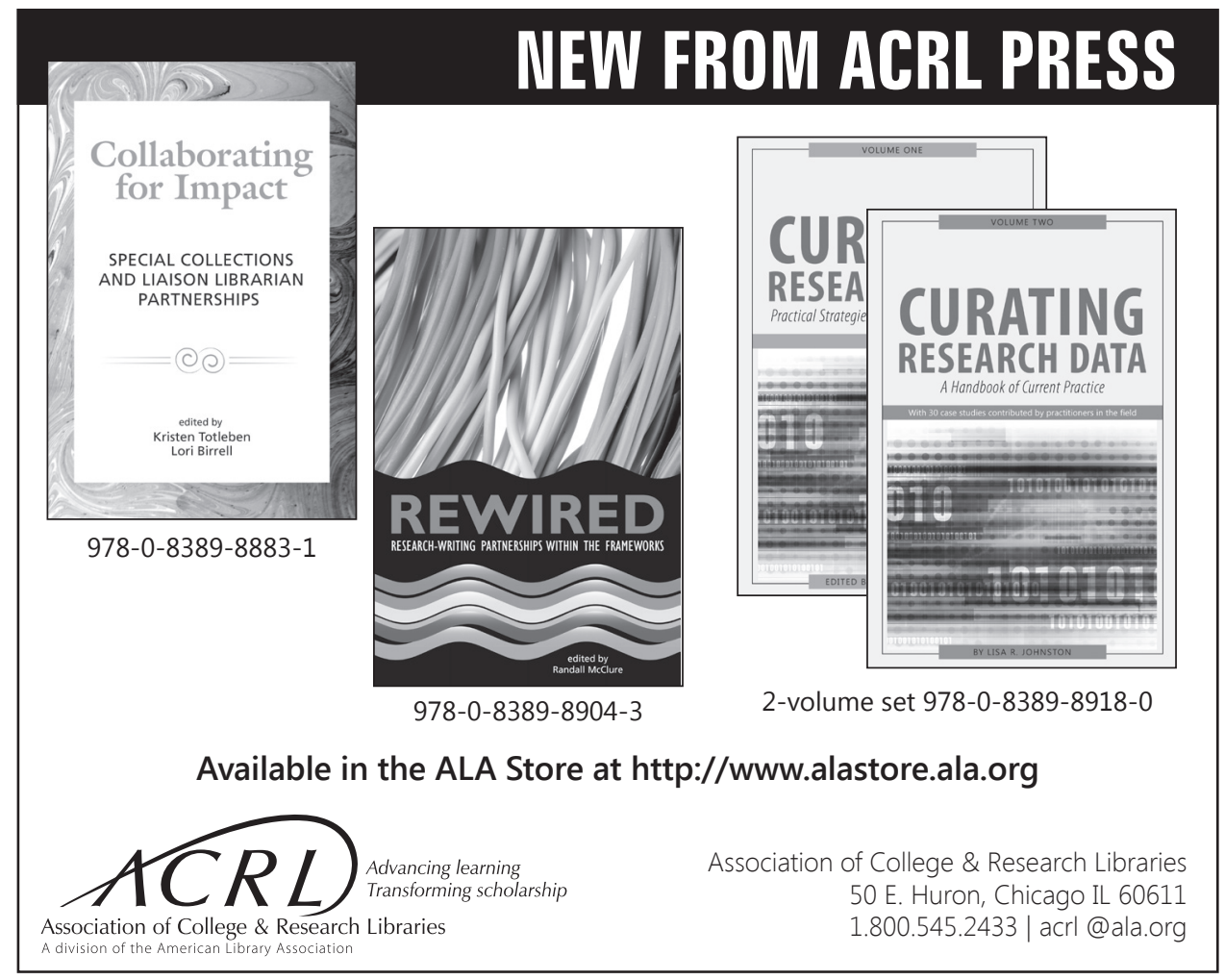

